\title{
An Academic Controversy at Iowa State Agricultural College, 1890-1891
}

\author{
EDWARD A. GOEDEKEN
}

\begin{abstract}
DURING THE LAST quarter of the nineteenth century, landgrant colleges shared a common dilemma: should the students receive a "narrow" education based solely on agriculture and related disciplines, or should the emphasis be "broadened" to prepare students for professional careers ${ }^{1}$ Most land-grant colleges solved this problem of academic emphasis by slowly broadening their curricula to include many subjects taught at older, classical colleges. ${ }^{2}$ Others, like Michigan State Agricultural College, remained firmly wedded to the principle of practical instruction. ${ }^{3}$ The Iowa State Agricultural College pat-
\end{abstract}

${ }^{1}$ For more on "broad" and "narrow" educational emphasis at land-grant schools see Earle D. Ross, Democracy's College: The Land-Grant Movement in the Formative Stage (Ames, Iowa: The Iowa State College Press, 1942), 8691. Additional information on the history of land-grant colleges can be found in Edward Danforth Eddy, Jr., Colleges for Our Land and Time: The LandGrant Idea in American Education (New York: Harper \& Brothers, 1957).

${ }^{2}$ For an example of midwestern land-grant college that followed a gradual trend towards the liberal arts see James C. Carey, Kansas State University: The Quest for Identity (Lawrence, Kansas: The Regents Press of Kansas, 1977), 39-87.

${ }^{3}$ For a history of Michigan State College see Madison Kuhn, Michigan 


\section{Academic Policy at Iowa State College}

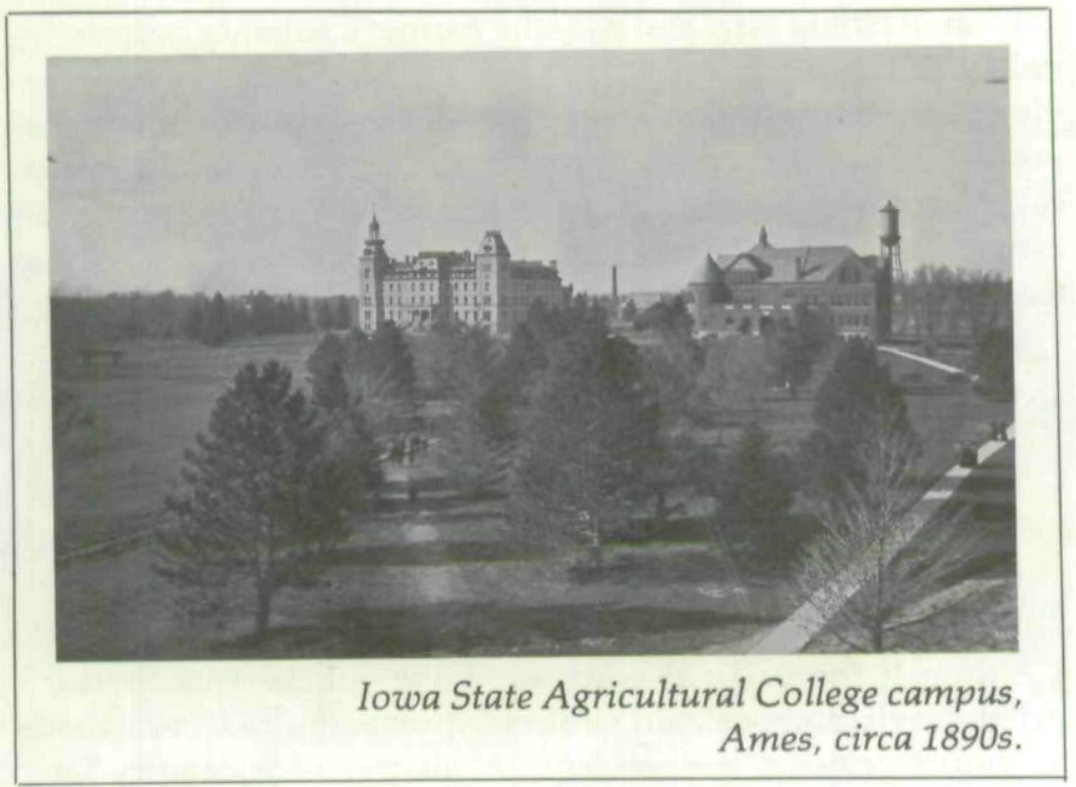

terned its development after the majority of land-grant colleges: gradually broadening its curriculum while simultaneously cutting back agriculture-related work. But this reduction of agricultural emphasis encountered strong opposition from the Iowa Farmer's Alliance. With the aid of the Iowa Homestead, the leading farm journal in the state, and other Iowa farm organizations, the Farmer's Alliance persuaded the college faculty and the Board of Trustees to reinstate a strong agriculture course. This change, effected only after a long and bitter debate, resulted in the hiring of a new college president and professor of agriculture. Most importantly, it represented a unique instance when the Farmer's Alliance took an active role in shaping academic policy at a land-grant college. ${ }^{4}$

State: The First Hundred Years (East Lansing, Michigan: Michigan State University Press, 1955). More information on specific land-grant schools and their curriculum development may be found in Alfred Charles True, A History of Agricultural Education in the United States, 1785-1925, U.S. Department of Agriculture, Miscellaneous Publication, No. 36 (Washington, D.C.: United States Government Printing Office, 1929), 129-91.

${ }^{4} \mathrm{~A}$ land-grant school which did receive support from the Farmer's Alliance is described in John K. Bettersworth, People's College: A History of Missis- 


\section{The Annals of Iowa}

To understand how and why the Farmer's Alliance became involved in the affairs of the college, it is necessary to briefly review the changes and modifications of the original college purpose. The 1858 Education Act, passed by the Iowa Legislature, called for the creation of "State Agricultural College and Model Farm to be connected with the entire Agricultural Interests of the State" and outlined the following course of general study:

Natural Philosophy, Chemistry, Botany, Horticulture, Fruit Growing, Animal and Vegetable Anatomy, Geology, Mineralogy, Meteorology, Entymology, Zoology, the Veterinary Art, Plain Mensuration, Levelling, Surveying, Book-Keeping, and such mechanic arts as are directly connected with Agriculture. Also such studies as the trustees may from time to time prescribe, not inconsistent with the purposes of this act. ${ }^{5}$

Although the original purpose of the college was to teach strictly agriculture-related subjects, provision had been made for future revision if necessary. A quarter of a century later revisions were introduced.

In 1884, Iowa State Senator P. M. Sutton proposed an amendment to the section of the 1873 Iowa State Code pertaining to the college in Ames. ${ }^{6}$ Sutton argued that the original 1858 act unintentionally excluded such subjects of general education as English, foreign languages, and mathematics. He recommended that the section of the act quoted above be repealed and replaced by the following:

That there shall be adopted and taught at the State Agricultural College a broad, liberal and practical course of study in which the leading branches of learning shall relate to agriculture and the mechanic arts, and which shall also embrace such other

sippi State (Birmingham, Alabama: University of Alabama Press, 1953), 14475. In states where there was little or no membership in the Farmer's Alliance the land-grant schools developed their curricula without noticeable input from farmers. For an example see William Murray Hepburn and Louis Martin Sears, Purdue University: Fifty Years of Progress (Indianapolis: The Hollenbeck Press, 1925), 51-100.

${ }^{5}$ Acts and Resolutions of the Seventh General Assembly: State of Iowa, 1858 (Des Moines: J. Teesdale, State Printer, 1858), 173-79.

${ }^{6}$ The Code: Containing all the Statutes of the State of Iowa of a General Nature (Des Moines: G. W. Edwards, State Printer, 1873), 299-303. 
branches of learning as will most practically and liberally educate the agricultural and industrial classes in the several pursuits and professions of life, including military tactics.?

With the passage of Sutton's amendment in March 1884, the college began broadening its curriculum to include "classical" subjects. The results of this trend toward more liberal arts served as the impetus for the subsequent controversy at the Iowa State Agricultural College.

PRIOR TO THE passage of the 1884 Sutton amendment, the number of students enrolled in the Agriculture course had grown to over 100 . The primary reason for this great interest in agriculture stemmed from the popularity of President Adonijah S. Welch and Professor of Agriculture Seaman A. Knapp. During his fifteen years at the college from 1868-1883, Welch worked diligently, strengthening agricultural instruction. Knapp, who arrived in 1879 as chairman of the Agriculture Department, developed courses stressing practical agriculture. After Welch was removed in 1883 because of friction within the faculty, Knapp served briefly as president. But the unstable climate at the college proved too much for him and he resigned in early $1887 .{ }^{8}$ With the departure of Welch and Knapp, and the passage of the Sutton amendment, student involvement in agriculture waned. By 1888 fewer than sixty students retained an interest in the subject. ${ }^{9}$

The college responded to the dwindling agricultural enrollments by dropping the Bachelor of Scientific Agriculture Degree in $1888 .{ }^{10}$ Now those majoring in agriculture would not receive a distinctive degree, but instead would earn the same bachelor of

${ }^{7}$ Earle D. Ross, A History of the Iowa State College of Agriculture and Mechanic Arts (Ames: The Iowa State Press, 1942), 382.

${ }^{8}$ Joseph Cannon Bailey, Seaman A. Knapp: Schoolmaster of American Agriculture (New York: Columbia University Press, 1945), 104-5.

"Robert M.Collins, "History of Agronomy At The Iowa State College" (Ph.D. dissertation, Iowa State College, 1953), 28-29.

${ }^{10}$ Iowa State College of Agriculture and Mechanic Art, Catalogue: 1889 (Ames: By the College, 1889), 32; lowa State College of Agriculture and Mechanic Art, Catalogue: 1890 (Ames: By the College, 1890), 35. 
science degree given all science students. This action signalled a radical departure from past policy and infuriated farmers' organizations.

In October 1888 the Iowa Homestead printed a stinging attack upon the college, marking the first indication of farmer dissatisfaction with the course combination. The writer, an anonymous "Agricola," branded the agricultural education at the college a "farce." Fuming because the Bachelor of Scientific Agriculture Degree had been dropped, Agricola noted there were only two students left in agriculture. He was firmly of the opinion that "any intelligent farm boy could learn more agriculture from the Iowa Homestead in one year than by going to college for two years." 11

Agricola's statements did not go unanswered. Joseph Dysart, chairman of the Board of Trustees, vigorously defended the school. He averred that the school was doing an excellent job teaching agriculture under the efficient administration of the new president, William Chamberlain, and dismissed Agricola's remarks as "rumors of downright slander" from a "disordered brain." 12

The Iowa Homestead became a willing forum for the ensuing debate. As the leading farm newspaper in the state, it had a great interest in the agricultural college's affairs. Founded in the 1850 s the Homestead went through several name changes and owners before coming under the ownership of James Pierce in 1885. Under the leadership of Pierce and the editorial influence of Henry Wallace, the Homestead soon gained statewide reputation as an authoritative farm journal. ${ }^{13}$

Henry Wallace, the father and grandfather of Henry C. and Henry A. Wallace, joined the Homestead in 1883 . He had been involved in lowa politics for many years. His slashing attacks on railroad monopolies and low prices for farm products were enthusiastically received by the Grange and the Farmer's Alliance, and both groups adopted the Homestead as their principal organ in the state. ${ }^{14}$ When the debate over the college curri-

${ }^{11}$ Iowa Homestead, October 5, 1888.

${ }^{12}$ Ibid., November 2, 1888.

${ }^{13}$ Gerald LeRoy Seaman, "A History of Some Early Iowa Farm Journals (Before 1900)," (Master's thesis, Iowa State College, 1942), 36-37.

${ }^{14}$ In his autobiography Wallace relates how he became editor of the Homestead and also tells of his activities in Iowa politics. Henry Wallace, Uncle 


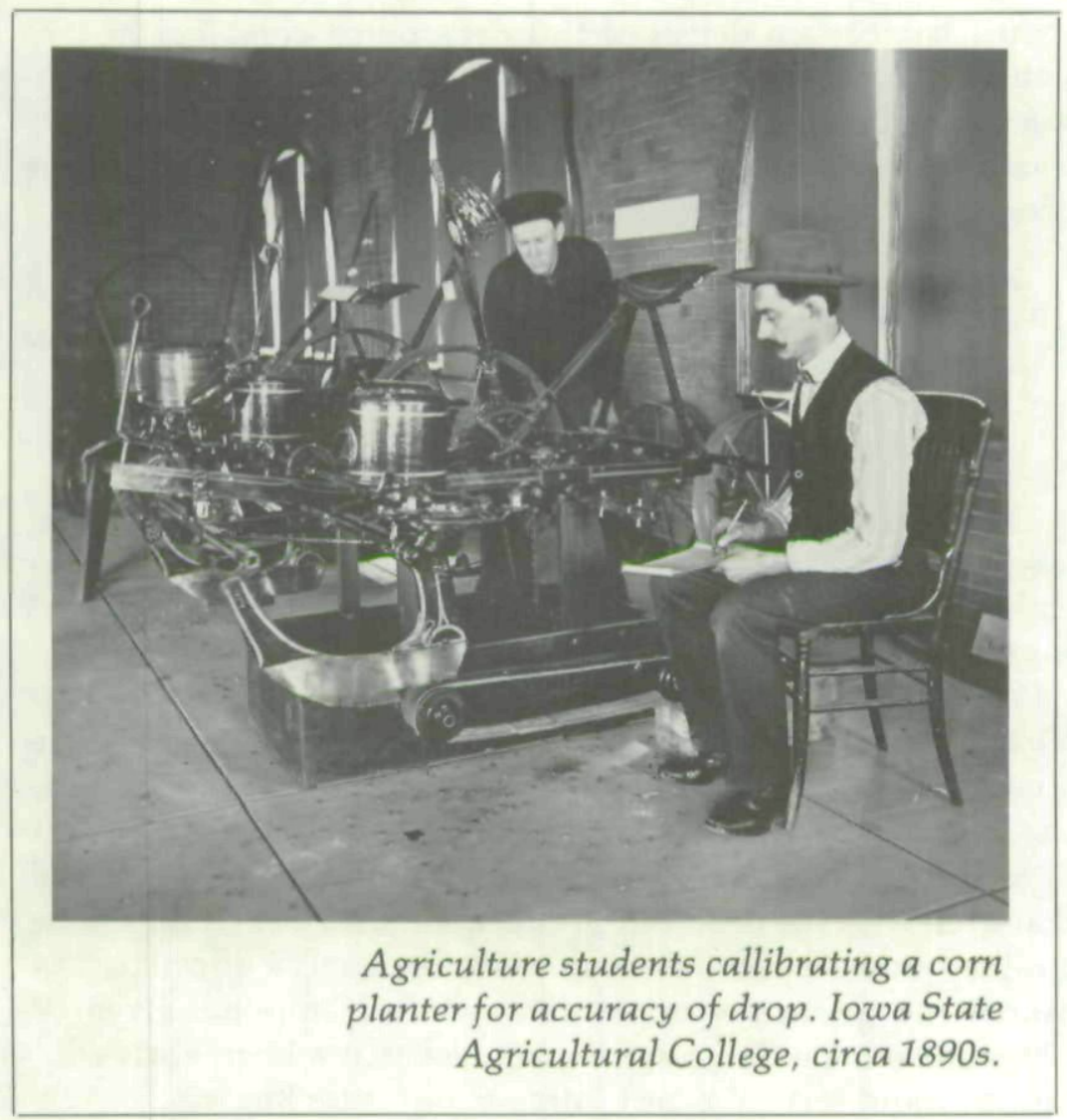

culum began, the Homestead naturally served as a tool for those advocating a renewed emphasis on agriculture at the landgrant college.

Although the dropping of the Bachelor of Scientific Agriculture Degree disturbed the farm groups, in the summer of 1889 the college further deemphasized agriculture by combining the Science Related to the Industries course with the Agriculture course. ${ }^{15}$ A distinct agricultural course no longer existed. Presi-

Henry's Own Story of His Life: Personal Reminiscences, 3 vols. (Des Moines, Iowa: Wallace's Publishing Company, 1917-1919), 3:29-38.

${ }^{15}$ The faculty recommended the course combination in November 1888. I.S.U. Library Archives, University Councils and Committees, General 


\section{The Annals of Iowa}

dent Chamberlain defended this decision to combine the two courses, explaining that the name "agriculture" college was inadequate and misleading. He stressed that the law clearly provided for a broad and liberal education. Thus the college taught:

Not simple processes in agriculture, horticulture, and mechanic arts, learned better and more cheaply in the shop or on the farm; not these do we teach largely, but related sciences, underlying principles, and processes too intricate or difficult for the unskilled, uneducated laborer. ${ }^{16}$

Chamberlain steadfastly believed that the college was not to teach strictly practical education, but should improve the general well-being of the student through exposure to classical studies and underlying theories.

Professor of Agriculture Loren Smith gave additional rationale for the course combination. He argued that it was "native ability" that made a successful man in any line of work, regardless of education. Therefore, any education was a help to a farmer, be it classical, scientific, or technical. Smith warned that even with the best college education a farmer could still be a failure since "education only makes one more effective, but cannot change the powers of mind which Nature has given."17 Chamberlain and Smith were confident that a liberal arts education would serve the best interests of future farmers.

The course combination and Chamberlain's and Smith's defense occurred in the summer of 1889 . Although the course revision was obviously resented by farm groups, nothing more was said about the affairs of the college for over a year. One possible reason for this apparent lack of interest lay in the fact that al-

Faculty: Minutes 1879-1889, Series 8/3/1, Box \#2, November 5 and 9, 1888. The Board of Trustees subsequently adopted the faculty recommendation in May 1889. I.S.U. Library Archives, Board of Trustees Reports (1880-May 1888) (November 1888-1894), May 16, 1889. Joseph Dysart announced the course combination decision in the Iowa Homestead on June 14, 1889.

${ }^{16}$ Thirteenth Biennial Report of the Board of Trustees of the Iowa State Agriculture College and Farm: 1888-1889 (Des Moines: G. W. Ragsdale, State Printer, 1889), 8.

${ }^{17}$ Ibid., 20. Italics in original. 
though the course combination was adopted in mid-1889, it was not put into practice until the following academic year starting in February 1890. A more probable cause for the extended silence lay in the fact that spring fieldwork was soon at hand and the attention of farmers and farm journals turned to crop production. The controversy revived, however, with the completion of the harvest in the fall.

By October 1890, the Iowa Farmer's Alliance, having lost patience with the college's refusal to reinstate the Agriculture course, took a more active part in the controversy. At the annual meeting of the Iowa Farmer's Alliance, a standing committee was formed to visit the college during the graduation exercises in November and impress upon the college officials the importance of promoting the "interests of agricultural education." 18 The alliance committee duly visited the college in November and met with the administration and faculty. They also took the opportunity to confer with the Board of Trustees during its regular fall meeting on campus.

Of the eleven men on the board, only one was a farmer; the remainder consisted of lawyers, doctors, and businessmen. Although weighted toward the professional side, they nevertheless were determined to view the controversy with open minds, and gave the farmer's groups ample opportunity to be heard.

The trustees greeted the alliance committee with the surprising news that Chamberlain and Smith were leaving the college. Although Chamberlain gave no explanation for his voluntary departure, the farm organizations assumed they were responsible. But Chamberlain's failure to settle a bitter conflict between fraternity and non-fraternity students that had flared up in May 1888 rocked his already shaky administration. ${ }^{19}$ The combination of the fraternity problem and the curriculum controversy overwhelmed the president. He elected to resign for the good of the college-and for himself.

Professor of Agriculture Smith joined the departing Chamber-

${ }^{18}$ Iowa Homestead, November 7, 1890.

${ }^{19}$ For an account of the fraternity problem see Ross, History of the Iowa State College, 183; John Boyd Hungerford, "Sketches of Iowa State College" (Unpublished manuscript, Iowa State College, 1940), 55-57. 


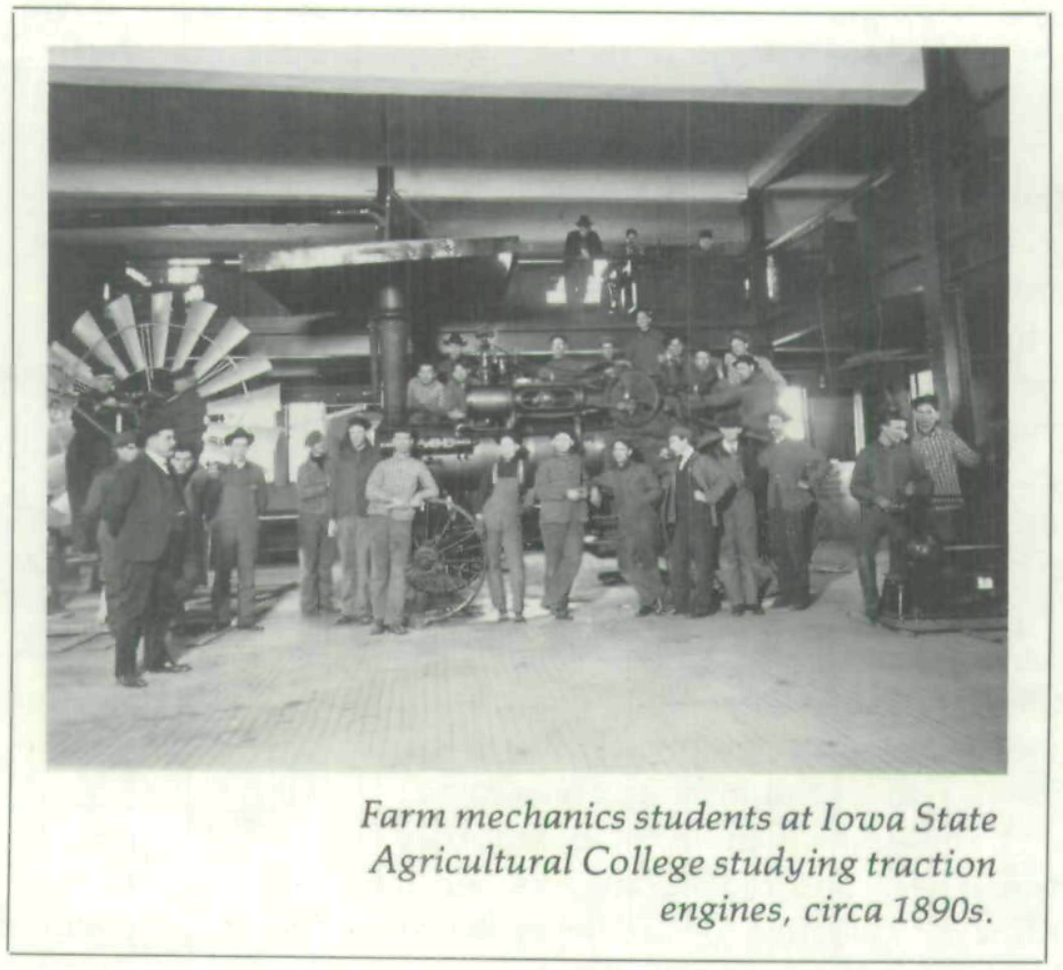

lain, explaining that he had "learned of some opposition to him by members of the faculty." ${ }^{20}$ Evidently the controversy had caused a split in the faculty, with Smith's opponents openly expressing their dissatisfaction with his performance. At any rate, the Board of Trustees was now left with the task of filling the two vacated positions.

While the trustees began their search for replacements, criticism of the college mounted. Those desiring a return to the days when practical agriculture was taught recognized the opportunity to shape the future of the school. A week after the resignations, the Homestead printed a belated attack on former Professor of Agriculture Smith. Another anonymous author-this time "Justice" - declared that Smith had known "nothing about western agriculture and preferred to play lawn tennis." What the school needed, Justice recommended, was an agriculture

${ }^{20}$ Board of Trustees Report, November 13, 1890. 
professor who knew midwestern agriculture and could teach it to Iowa farm boys. Justice insisted that the school at Ames remain "agricultural and different from the other schools in Iowa." 21

In response to the growing pressure to change the curriculum, John L. Budd, professor of horticulture wrote a letter to the Iowa State Register defending the course combination. He strongly supported Chamberlain's view that the "natural sciences should be a part of agricultural study." Budd pointed to the organic law to give credence to his opinion and reminded his readers that the law provided for a general preparation for citizenship at the college. He refused to accept the idea that all liberal arts courses should be eliminated from the curriculum, and stated that they should remain an integral part of any student's education. ${ }^{22}$

The following week, a student from the college answered Budd's remarks in a long letter to the Iowa Homestead. The student acknowledged that some sciences might be necessary for agricultural study, but he failed to understand the importance of subjects like German or Latin. The elimination of these unnecessary courses and the incorporation of a new agricultural course, separate from the sciences, was what the college needed, the student insisted. ${ }^{23}$

In response to the stories and letters appearing in the Iowa State Register and the Iowa Homestead, the Iowa Improved Stock Breeders Association directed its influence toward achieving a new agriculture course. At its yearly meeting in early December 1890, the Stock Breeders' Association nominated James Wilson-known as "Tama Jim" Wilson-to chair a committee to investigate the college situation. Wilson had gained a reputation throughout the state as an expert in cattle production and wrote a syndicated column on the subject. He was a close friend of Henry Wallace and shared his concern about the lack of agricultural instruction at the college. ${ }^{24}$ Wilson, after serving

${ }^{21}$ Iowa Homestead, November 28, 1890.

${ }^{22}$ Iowa State Register, November 26, 1890.

${ }^{23}$ Iowa Homestead, December 5, 1890.

${ }^{24}$ Wilson clearly expressed the sentiment of the farm groups in a brief but fiery article in the Traer Star-Clipper, January 9, 1891: "There will not be peace ... until the school at Ames makes education relative to the farm its 
three successive terms in Congress, was appointed Secretary of Agriculture by President William McKinley in 1897. The committee produced the following recommendations for the Board of Trustees: (1) a request that the board completely review the existing course of study, eliminating from the curriculum all courses not relating directly to science and agriculture; and (2) establish a short course in agriculture during the winter months. These recommendations were seconded by the Homestead. ${ }^{25}$

FINALLY the day of decision arrived. In a special session on January 8, 1891 the Board of Trustees met to find a solution to the problem. The Register praised the board for having "patiently borne much abuse and misrepresentation from persons and papers not fully informed of the facts." The newspaper rejected any notion that the trustees would vote to exclude any of the science, literary, or engineering courses already existing at the school. Such action "would be suicide for the college." One board member was quoted as stating that the college "should remain a place where a farmer's son or daughter can go .... and get a liberal education in something besides plowing." ${ }^{26}$ The board seemed firmly against compromise with the farm organizations. Fortunately, the final results of its deliberations showed that the efforts by the alliance, and related organizations, had not been in vain.

The day before the scheduled board meeting, the trustees and faculty met to revise the Science and Agriculture course. When the board officially met on January 8, Acting President Edgar Stanton presented the agreed-upon recommendations: (1) a short course in agriculture for the winter months; (2) a college preparatory course for entering students; and (3) a new and distinct four-year course in agriculture. ${ }^{27}$ These proposals were remarkably similar to those advanced by the Farmer's Alliance

prime object. Every professor who turns up his nose must walk. Every trustee who is not in sympathy must stand aside. Other professors must keep hands off. Iowa, the greatest farming state in the Union, is so far behind some other states that the knowledge of it is burning like a prairie fire."

${ }^{25}$ Iowa Homestead, December 12, 1890.

${ }^{26}$ Iowa State Register, January 8, 1891.

${ }^{27}$ Board of Trustees Report, January 8, 1891. 
and the Stock Breeders' Association. The farmers in Iowa now had a distinctive agriculture course again and the liberal trend that began in the early 1880 s was reversed. Although the board refused to go as far as Wallace and others had desired-a complete elimination from the curriculum of all studies not directly relating to agriculture-they had brought about a compromise by creating the short winter course and the regular four-year course.

Having resolved the curriculum question, the board turned its attention to selecting replacements for Chamberlain and Smith. The Farmer's Alliance had strongly recommended that the board choose men who were native Iowans, not previously associated with the college ${ }^{28}$ For president, the alliance recommended William Beardshear. As superintendent of the West Des Moines Schools, Beardshear had demonstrated high administrative abilities and had impressed several members of the board. ${ }^{29}$ For professor of agriculture, the faculty initially sought Henry Wallace. But he modestly declined, suggesting instead James Wilson. Wilson was highly esteemed by farm interests in the state and his nomination received hearty approval from the alliance. ${ }^{30}$

The board quickly acceded to the alliance recommendations and unanimously hired Beardshear and Wilson. A new president, professor of agriculture, and Agriculture course were now a part of the college again. More importantly, a decision had been made to reverse the liberal trend and reinstate the "stiffest

${ }^{28}$ In an open letter to the Board of Trustees one farmer declared that the college should be "managed by Iowa men-from the president down to the janitor-men whose every interest is in Iowa, and who are thoroughly imbued with the spirit of progress now extant in this state ..." Iowa Homestead, December 12, 1890.

${ }^{29}$ Charles F. Saylor, a member of the board, had become close friends with Beardshear while serving as superintendent of the Polk County schools and recommended Beardshear to the other board members. Hungerford, 144.

${ }^{30} \mathrm{Wilson}$ and Beardshear had become acquainted several years earlier when Beardshear served as president of Western College at Toledo, Iowa. Wilson had been active in civic and educational affairs in Tama County. Hungerford, 145. In his memoirs, Wallace gives an interesting account of his efforts to gain Wilson the agriculture position. Henry Wallace, Uncle Henry's Own Story, 3: 49-51. 
agriculture course in the United States." ${ }^{13}$ The Homestead and the Register joined in praising the board's actions. The Register confidently predicted that Beardshear would help the college grow "by emphasizing practical aspects of education, not at the expense of the other classical courses." ${ }^{32}$ The Homestead renewed its support for the college and urged farmers in the state to send their sons and daughters to the school: "Here the student has a place now, and a good, big one." ${ }^{\prime 33}$

The unique reversal in academic emphasis was the result of a coordinated effort by the Farmer's Alliance, the Iowa Homestead, and other farm organizations, such as the Iowa Improved Stock Breeders' Association. Unlike Kansas and Mississippi, where the alliance was generally supportive, or Indiana where farm groups did not exercise their influence, the Iowa alliance and its fellow organizations forced their will upon the college. Without the renewed emphasis on agricultural study at the Iowa Agricultural College in 1891, the present-day university would not have the reputation it enjoys as one of the most outstanding agricultural schools in the United States.

${ }^{31}$ Wilson had promised this upon his selection as professor of agriculture, Iowa State Register, January 10, 1891.

${ }^{32}$ Ibid., January 10, 1891.

${ }^{33}$ Iowa Homestead, January 16, 1891. 
Copyright of Annals of Iowa is the property of State of Iowa, by \& through the State Historical Society of Iowa and its content may not be copied or emailed to multiple sites or posted to a listserv without the copyright holder's express written permission. However, users may print, download, or email articles for individual use. 